MEDEIROS, AM; RODRIGUES, R; COSTA, DV; PIMENTA, S; OLIVEIRA, JG. 2018. Non-parametric indexes in selecting hybrids of chili pepper. Horticultura Brasileira 36: 027-032. DOI - http://dx.doi.org/10.1590/S0102-053620180105

\title{
Non-parametric indexes in selecting hybrids of chili pepper
}

\author{
Artur M Medeiros ${ }^{1}$; Rosana Rodrigues²; Daniele V Costa²; Samy Pimenta ${ }^{3}$; Jurandi G Oliveira ${ }^{2}$
}

${ }^{1}$ Universidade Federal do Piauí (UFPI), Bom Jesus-PI, Brazil; artur.medeiros@ufpi.edu.br; ${ }^{2}$ Universidade Estadual do Norte Fluminense Darcy Ribeiro (UENF), Campos dos Goytacazes-RJ, Brazil; rosana@uenf.br; danieleviana@agronoma.eng.br; jugo@uenf.br; ${ }^{3}$ Universidade de Montes Claros (UNIMONTES), Montes Claros-MG, Brazil; pimentasamy@gmail.com

\section{ABSTRACT}

On Solanaceae, the use of hybrids in seed market has been consolidated in recent decades, especially for sweet pepper and tomato crops. However, other crops such as chili peppers (Capsicum spp.) are still neglected by breeding programs which aim to obtain hybrids. The objectives of this work were to evaluate experimental chili pepper hybrids dedo-de-moça (C. baccatum var. pendulum) in relation to production and quality of fruits in two growing seasons and to compare non-parametric selection indexes based on these aspects. Eight chili pepper genotypes were evaluated, being three experimental hybrids (HP03, HP04 and HP08), three lineages (PIM01, PIM02 and PIM03) and two commercial cultivars as controls ('BRS Mari' and 'Ibirajá'), under field conditions in two growing seasons (autumn/winter and spring/summer) in the municipality of Campos dos Goytacazes, Rio de Janeiro state, Brazil. The number of days to flowering, number of fruits per plant, average fruit mass, fruit length, fruit diameter, yield, fruit dry mass, titratable acidity, ascorbic acid and soluble solids content were evaluated. A highly significant difference among genotypes for all evaluated parameters was obtained. Significant interaction was observed for genotypes $\mathrm{x}$ growing seasons only for fruit length, fruit dry mass and ascorbic acid content, considering the last two ones of a complex nature. Chili pepper hybrids tested had a constant performance in the two growing seasons based on agronomic and physicochemical characteristics. By the selection indexes used, the superiority of the hybrid HP03 in relation to the other evaluated genotypes was verified. In addition to the evaluated agronomic and physicochemical parameters, this hybrid stands out for having a differentiated and innovative shape of chili pepper, since no such hybrid has been found in the Brazilian market until then. Mulamba \& Mock and Genotype-Ideotype selection indexes were concordant in the selection of the three best genotypes.

Keywords: Capsicum baccatum var. pendulum, Schwarzbach Index, cultivars registration, chili pepper fruits, nutritional value.

\section{RESUMO}

Índices não paramétricos na seleção de híbridos de pimenta

Nas solanáceas, a utilização de híbridos no mercado de sementes se consolidou nas últimas décadas, em especial nas culturas do pimentão e do tomateiro. Entretanto, outras culturas como as pimentas (Capsicum spp.) ainda são tratadas de forma incipiente pelos programas de melhoramento que visam a obtenção de híbridos. Os objetivos desse trabalho foram avaliar híbridos experimentais de pimenta dedo-de-moça (C. baccatum var. pendulum) quanto a aspectos de produção e qualidade de frutos em duas épocas de cultivo e comparar índices de seleção não-paramétricos com base nesses caracteres. Foram avaliados oito genótipos de pimenta, sendo três híbridos experimentais (HP03, HP04 e HP08), três linhagens (PIM01, PIM02 e PIM03) e duas testemunhas comerciais ('BRS Mari' e 'Ibirajá'), em condições de campo em duas épocas de cultivo (outono/inverno e primavera/verão) no município de Campos dos Goytacazes-RJ. Avaliaram-se as características número de dias para florescimento, número de frutos por planta, massa média do fruto, comprimento do fruto, diâmetro do fruto, produtividade, massa seca do fruto, acidez titulável, ácido ascórbico e teor de sólidos solúveis. Houve diferença altamente significativa entre os genótipos para todos os caracteres avaliados. Verificou-se interação genótipos x épocas de cultivo significativa somente para comprimento do fruto, massa seca do fruto e conteúdo de ácido ascórbico, sendo os dois últimos de natureza complexa. Os híbridos de pimenta dedo-de-moça testados tiveram um desempenho constante nas duas épocas de cultivo com base em características agronômicas e físico-químicas de frutos. Pelos índices de seleção utilizados, constatou-se a superioridade do híbrido HP03 em relação aos demais genótipos avaliados. Além dos caracteres agronômicos e físico-químicos avaliados, este híbrido destaca-se por ter um formato dedo-de-moça diferenciado e inovador, pois não há no mercado brasileiro um híbrido deste tipo até então. Os índices de seleção Mulamba \& Mock e Genótipo-Ideótipo foram concordantes na seleção dos três melhores genótipos.

Palavras-chave: Capsicum baccatum var. pendulum, Índice de Schwarzbach, registro de cultivares, frutos de pimenta, valor nutricional.

\section{Received on May 4, 2016; accepted on May 8, 2017}

$\mathrm{P}$ eppers are among the most important crops of Solanaceae family grown in the world (Mahmoud et al., 2015). Besides being marketed in natura, this crop supplies agro-industry in the form of condiments, spices, seasonings and preserves, occupying a prominent place among the condiment species (Rebouças et al., 2013).

The genus Capsicum has 38 reported species, all of them from the American continent, but only five are considered domesticated (C. annuum, C. chinense, C. frutescens, C. baccatum and $C$. pubescens). The species $C$. baccatum is represented by botanic varieties C. baccatum var. baccatum and $C$. baccatum var. pendulum. This last one is the most consumed in South and Southeast Regions of Brazil, being popularly known as dedo-de- 
moça (elongated fruit) or cambuci (campanulated fruit), respectively (Barboza et al., 2011).

The development of new cultivars with resistance to biotic and abiotic stresses, high yield and fruit quality are the main aims for chili pepper breeding programs (Rêgo et al., 2009; Rodrigues et al., 2012). However, this is not an easy task, since the characters on which the breeders work, for the most part, are quantitative (Ramalho et al., 2012). Moreover, pepper is cultivated in different regions or at different times in the same region, in several types of soil, temperature, photoperiod, humidity, rainfall and cultural practices (Rebouças et al., 2013). These genetic and environmental factors can interact, making in many cases, the performance of the genotypes in the different environments not coincident (Ramalho et al., 2012; Cruz et al., 2012).

The evaluation of new cultivars in trials made in different growing periods allows obtaining important information on agronomic performance and the possibility to give a safer recommendation to the producer (Ramalho et al., 2012). In the evaluation of these cultivars, the observation of a series of attributes that gives the highest yield and satisfies the requirements of the producer and consumer are necessary, and the use of these pieces of information simultaneously becomes essential. According to Cruz et al. (2012), a way to increase the chance of success of breeding programs is through a simultaneous selection of a set of traits of economic importance by selection indexes.

The selection indexes can be classified as parametric and nonparametric (Cruz et al., 2012). These indexes differ due to the necessity, or not, of estimation of the covariance parameters and genetics and phenotypic variances. The use of the parametric indexes requires the estimation of such parameters, as an example, the indexes of Pesek \& Baker (1969) and Smith et al. (1981). The non-parametric indexes do not require these estimations. These indexes have been used, for example, in the selection of banana diploid hybrids (AA) (Lessa et al., 2010), in the combined selection in segregating progenies of papaya (Pinto et al., 2013), arrangement of half-brother families of conilon coffee (Carias et al., 2016), selection of pepper $F_{2}$ genotypes (Oliveira et al., 2015) among others.

The aims of this study were to evaluate experimental hybrids of chili pepper dedo-de-moça (C. baccatum var. pendulum) in relation to production and quality of fruits in two growing seasons and compare these indexes with non-parametric selection based on these aspects.

\section{MATERIAL AND METHODS}

The evaluated genotypes were three pure lines, identified as PIM01, PIM02 and PIM03, and three experimental hybrids of chili pepper (HP03, HP04 and HP08), obtained from Capsicum spp. breeding program of UENF (Gonçalves et al., 2011; Rodrigues et al., 2012; Medeiros et al., 2014). All hybrids were considered dedo-de-moça type, although two are classified as campanulated by the descriptor format of the fruit of Bioversity International, since they have the highest diameter in the central region, being far elongated, with more than $80 \mathrm{~mm}$ length, visually similar to dedo-de-moça chili pepper. In the absence of commercial hybrids of dedo-de-moça chili pepper, the cultivars BRS Mari (C. baccatum var. pendulum, pure-line cultivar) and Ibirajá (C. annuum, hybrid cultivar) were used as controls (Table 1). The experimental design was completely randomized, with three replicates. The experimental plots consisted of 16 plants, in four rows with four plants. Spacing between rows and plants were of 1.2 and $1.0 \mathrm{~m}$, respectively.

The experiments were installed under field conditions in two growing seasons. The first (autumn/winter) from March to August, 2013, at Unidade de Apoio à Pesquisa, Campus from UENF (2145'23'S, 41 ${ }^{\circ} 19^{\prime} 40^{\prime \prime} \mathrm{W}$ and $14 \mathrm{~m}$ altitude) on a Haplic Cambisol. The second season (spring/summer) from October, 2013 to March, 2014, in the partnership area of UENF with Centro Estadual de Pesquisa em Agroenergia e Aproveitamento de Resíduos (State
Center for Research in Agroenergy and Waste Utilization) (21 ${ }^{\circ} 44^{\prime} 47^{\prime \prime} \mathrm{S}$, $41^{\circ} 18^{\prime} 24^{\prime \prime} \mathrm{W}, 11 \mathrm{~m}$ altitude) on Fluvic Neossol Tb Distrophic. Both areas located in Campos dos Goytacazes. The climate in the region, according to Köppen and Geiger, is Aw, humid tropical, with rainy summer and dry winter. The minimum and maximum average temperatures are $20.3^{\circ} \mathrm{C}, 25^{\circ} \mathrm{C}$ and $87 \%$ during the first season and $22.6^{\circ} \mathrm{C}, 26.6^{\circ} \mathrm{C}$ and $80 \%$ during the second season, respectively.

Fertilization was based on soil analysis, according to the recommendation for the State of Rio de Janeiro (De-Polli, 1988), and cultural practices were done according to the recommendation for the crop (Filgueira, 2012), such as manual hoeing, individualized tutoring and sprinkler irrigation.

Seven agronomic and three physicochemical traits were evaluated. The evaluated agronomic traits were: days to flowering (DFL), number of fruits per plant (NFP), average fruit mass (AFM, in $\mathrm{g}$ ), fruit length (FL, in $\mathrm{mm}$ ), fruit diameter (DF, in $\mathrm{mm}$ ), yield $\left(\mathrm{Y}\right.$, in $\left.\mathrm{t} \mathrm{ha}^{-1}\right)$ and fruit dry mass (FDM, in $\mathrm{g} / 100 \mathrm{~g}$ of fresh mass), whereas the physicochemical traits were: titratable acidity (TA, in \% of citric acid); ascorbic acid (AAC, in mg/100 $\mathrm{g}$ of fruit fresh mass) and soluble solids content (SSC, in ${ }^{\circ}$ Brix). Six harvests were done in each of the evaluated growing seasons.

The data were submitted to the analyses of variance per environment and then the homogeneity of residual variances was verified using F-max considering the relationship between the highest and the lowest mean square error. The joint analysis was performed using the following model:

$Y_{i j k}=\mu+G_{i}+A_{j}+G A_{i j}+(B / A)_{j k}+\varepsilon_{i j k}$,

where: $\mu=$ overall mean, $\mathrm{G}_{\mathrm{i}}=$ (fixed) effect of $i^{\text {th }}$ genotype $(i=1,2, \ldots, g), A_{\text {. }}$ (fixed) $=$ effect of the $\mathrm{j}^{\text {th }}$ environment $(j=1,2, \ldots, a), G A_{i j}=$ interaction effect between $i^{\text {th }}$ genotype and $j^{\text {th }}$ environment, $\mathrm{B} / \mathrm{A}_{\mathrm{jk}}=$ effect of $\mathrm{k}^{\text {th }}$ block inside $\mathrm{j}^{\text {th }}$ environment $(\mathrm{k}=1,2, \ldots, \mathrm{r})$,

$$
\boldsymbol{\varepsilon}_{\mathrm{ijk}}=\text { experimental error. }
$$

Interaction partitioning was carried out using the algorithm of Cruz \& 
Castoldi (1991) by the expression:

$$
C=\sqrt{(1-r)^{3}} \sqrt{Q_{1} Q_{2}}
$$

where: $\mathrm{Q}_{1}$ and $\mathrm{Q}_{2=}$ average squares of the genotypes in the environments 1 and 2 , respectively, and $r=$ the correlation between averages of genotypes in two environments.

Genotypes were classified using Genotype-Ideotype distance selection indexes (Schwarzbach, 1972) and sum of classification (Mulamba \& Mock, 1978). The characters of greater economic importance were used: DFL, Y, FDM, TA, AAC and SSC, considering that for DFL and TA, the lowest average genotypes were selected and for the other traits the highest average genotypes were selected. Economic weights equal to 1 were attributed to each analyzed trait, with exception for yield, which received 2. Since genotypes $x$ growing season interaction was significant and complex for only two evaluated traits, the indexes were applied based on the average of the two seasons.

For sum of classification index (Mulamba \& Mock, 1978) the following expression was adopted:

$$
I_{M M i}=\sum_{j=1}^{m} n_{i j}
$$

where: $\mathrm{I}_{\mathrm{MMi}}=$ sum of classification index, in which $n_{\mathrm{ij}}$ is the number of the genotype classification $i$ in relation to character $j$.

Using Genotype-Ideotype distance index, the authors adopted Euclidean distance:

$$
D_{i l}=\sqrt{\sum_{j=1}^{m} d_{i j}^{2}}
$$

where: $\mathrm{D}_{\mathrm{iI}}=$ the Euclidean distance between genotype $i$ and ideotype I; $\mathrm{d}_{\mathrm{ij}=}$ the standard deviation between the average of the character $j$, measured in genotype $\mathrm{I}\left(\mathrm{X}_{\mathrm{ij}}\right)$, value for this character $\left(\mathrm{x}_{\mathrm{ij}}\right)$, that means, $d_{i j}=\left(X_{i j-} x_{i j}\right) / \sigma j$. Standardization prevents characters measured in larger units exert a greater influence than the others on the index value, and consequently, on the genotype classification.

In the definition of the ideotype, necessary for the calculation of the Genotype-Ideotype distance index, the best average of each evaluated trait was considered. The averages were compared using Tukey test $(\mathrm{p}<0.05)$.
All the statistic analyses were performed using Genes software (Cruz, 2016).

\section{RESULTS AND DISCUSSION}

Using F-max, the authors verified that the ratio MSmax/MSmin of errors between the growing seasons in the study were inferior to seven for all the evaluate traits. Therefore, the residual variances were considered homogeneous, which allows the joint analysis of data (Ramalho et al., 2012).

The results of the joint analysis of variance showed estimates of experimental variation coefficient $(\mathrm{CV})$ ranging from $4.76 \%$ for DFL to $28.08 \%$ with the values obtained by Rodrigues $e t$ al. (2012) who obtained values for CV ranging from $2.06 \%$ for DFL to 23.90 for Y. Coefficient of variation for AFM, FL and DF was considered, high, low and very high, respectively, according to the classification proposed by Silva et al. (2011). These coefficient of variation values are justified by the fact that the evaluated traits were quantitative and, therefore, very influenced by the environmental effect (Cruz et al., 2012).

A highly significant difference between the genotypes for all the evaluated traits was observed. For source of variation growing season, with the exception for fruit diameter, yield and soluble solids content, a significant difference for the other traits was noticed. A significant interaction genotypes $\times$ cultivation seasons only for FL, FDM and AAC was observed, showing that for AFM. These values are in accordance

the evaluated genotype performance was constant for most of the traits evaluated in the two growing seasons, as for example, the yield. According to Ramalho et al. (2012), the absence of genotype-environment interaction facilitates when a cultivar is supposed to be recommended to the farmer, since that when no interaction is noticed, the cultivar performance remains constant in different environmental conditions.

For number of days to flowering, HP03 did not differ significantly from the earlier control 'Ibirajá' (Table 2). This result was expected, since one of the attributes of this hybrid is earliness. Rodrigues et al. (2012) observed negative heterosis for days to flowering when studying 15 pepper genotypes, including some hybrids evaluated in this study. Negative heterosis for days to flowering was also verified by Singh et al. (2014), evaluating 66 pepper hybrids (C. annuum). Negative heterosis manifestation can be interesting in relation to the studied trait, for example, in the case of crop cycle reduction, increasing earliness and helping the producer start harvesting earlier.

In general, the average values obtained from the genotypes for number of fruits per plant ranged from 32 to 237 (Table 2). The highest values for number of fruits per plant were obtained from the commercial control 'BRS Mari' and line PIM02, which produced 237 and 229 fruits, respectively (Table 2). The values of number of fruits per plant obtained for hybrids ranged from 112 to 124. These values, lower than the ones

Table 1. Morphoagronomic traits of three experimental hybrids of chili pepper, three inbred lines and two commercial cultivars. Campos dos Goytacazes, UENF, 2016.

\begin{tabular}{lcc}
\hline Genotypes & Fruit shape & Ripe fruit color \\
\hline HP03 & Campanulated & Red \\
HP04 & Elongated & Red \\
HP08 & Campanulated & Red \\
PIM01 & Elongated & Yellow-orange \\
PIM02 & Elongated & Red \\
PIM03 & Elongated & Red \\
'BRS Mari'1 & Triangular & Dark red \\
'Ibirajá' & Elongated & Red \\
\hline
\end{tabular}

${ }^{1}$ Cultivar of inbred line type (C. baccatum var. pendulum $) ;{ }^{2}$ Hybrid cultivar (C. annuum). All genotypes have an indeterminate growth habit and all genotypes with the exception of PIM03 are pungent. 
Table 2. Means of agronomic and physicochemical traits ${ }^{1 /}$ evaluated in three experimental hybrids, three inbred lines of $C$. baccatum var. pendulum and two controls of commercial cultivars in two seasons. Campos dos Goytacazes, UENF, 2013-2014.

\begin{tabular}{|c|c|c|c|c|c|c|}
\hline \multirow{2}{*}{ Genotypes } & \multicolumn{6}{|c|}{ Means of traits ${ }^{1 /}$} \\
\hline & DFL & NFP & AFM & FL & DF & $\mathbf{Y}$ \\
\hline HP03 & $81.66 \mathrm{~cd}$ & $123.18 \mathrm{~b}$ & $15.71 \mathrm{a}$ & $82.62 \mathrm{~b}$ & $42.19 \mathrm{a}$ & $13.7 \mathrm{a}$ \\
\hline HP04 & $83.00 \mathrm{bc}$ & $124.67 \mathrm{~b}$ & $9.41 \mathrm{bcd}$ & $107.15 \mathrm{a}$ & $25.25 \mathrm{~cd}$ & $10.17 \mathrm{ab}$ \\
\hline HP08 & 84.00 bc & $112.22 \mathrm{bc}$ & $12.52 \mathrm{ab}$ & $88.36 \mathrm{~b}$ & $36.85 \mathrm{ab}$ & $8.65 \mathrm{ab}$ \\
\hline PIM01 & $85.33 \mathrm{bc}$ & $76.67 \mathrm{~d}$ & $10.40 \mathrm{abc}$ & $105.80 \mathrm{a}$ & $24.91 \mathrm{~cd}$ & $5.81 \mathrm{bc}$ \\
\hline PIM02 & $96.33 \mathrm{a}$ & $229.49 \mathrm{a}$ & $5.74 \mathrm{~cd}$ & $81.86 \mathrm{~b}$ & $19.61 \mathrm{de}$ & $9.36 \mathrm{ab}$ \\
\hline PIM03 & $83.66 \mathrm{bc}$ & $66.58 \mathrm{~d}$ & $13.15 \mathrm{ab}$ & $101.49 \mathrm{a}$ & $32.91 \mathrm{bc}$ & $6.94 \mathrm{bc}$ \\
\hline 'BRS Mari’ & $90.50 \mathrm{ab}$ & $237.45 \mathrm{a}$ & $4.14 \mathrm{~d}$ & $64.62 \mathrm{c}$ & $15.22 \mathrm{e}$ & $8.69 \mathrm{ab}$ \\
\hline \multirow[t]{3}{*}{ ‘Ibirajá' } & $73.33 \mathrm{~d}$ & $32.37 \mathrm{~d}$ & $9.83 \mathrm{bc}$ & $91.06 \mathrm{~b}$ & $29.20 \mathrm{bc}$ & $2.41 \mathrm{c}$ \\
\hline & \multicolumn{2}{|c|}{ FDM } & TA & \multicolumn{2}{|c|}{ AAC } & \multirow{2}{*}{ SSC } \\
\hline & AMB 1 & AMB 2 & IA & AMB 1 & AMB 2 & \\
\hline HP03 & $16.46 \mathrm{a}$ & $17.67 \mathrm{a}$ & $0.123 \mathrm{bc}$ & $111.19 \mathrm{a}$ & $59.81 \mathrm{abc}$ & $8.6 \mathrm{abc}$ \\
\hline HP04 & $14.57 \mathrm{abc}$ & $14.76 \mathrm{bc}$ & $0.153 \mathrm{ab}$ & $60.40 \mathrm{bcd}$ & $42.78 \mathrm{c}$ & $8.06 \mathrm{bcd}$ \\
\hline HP08 & $13.97 \mathrm{abc}$ & $16.22 \mathrm{abc}$ & $0.134 \mathrm{bc}$ & $48.42 \mathrm{~cd}$ & $50.94 \mathrm{c}$ & $7.20 \mathrm{~d}$ \\
\hline PIM01 & $15.39 \mathrm{ab}$ & $13.99 \mathrm{c}$ & $0.113 \mathrm{c}$ & $97.35 \mathrm{ab}$ & $70.34 \mathrm{ab}$ & $8.87 \mathrm{ab}$ \\
\hline PIM02 & $15.67 \mathrm{ab}$ & $15.31 \mathrm{abc}$ & $0.138 \mathrm{bc}$ & $77.40 \mathrm{abc}$ & $53.27 \mathrm{bc}$ & $8.72 \mathrm{ab}$ \\
\hline PIM03 & $10.59 \mathrm{bc}$ & $13.85 \mathrm{c}$ & $0.134 \mathrm{bc}$ & $37.85 \mathrm{~d}$ & $45.16 \mathrm{c}$ & $7.68 \mathrm{bcd}$ \\
\hline 'BRS Mari’ & $16.75 \mathrm{a}$ & $17.11 \mathrm{ab}$ & $0.187 \mathrm{a}$ & $89.27 \mathrm{ab}$ & $45.58 \mathrm{c}$ & $9.64 \mathrm{a}$ \\
\hline 'Ibirajá' & $9.540 \mathrm{c}$ & $15.85 \mathrm{abc}$ & $0.105 \mathrm{c}$ & $36.87 \mathrm{~d}$ & $72.53 \mathrm{a}$ & $7.35 \mathrm{~cd}$ \\
\hline
\end{tabular}

${ }^{1 /} \mathrm{DFL}=$ number of days to flowering; $\mathrm{NFP}=$ number of fruits per plant; $\mathrm{AFM}=$ average fruit mass $(\mathrm{g}) ; \mathrm{FL}=$ fruit length $(\mathrm{mm}) ; \mathrm{DF}=$ fruit diameter $(\mathrm{mm}) ; \mathrm{Y}=$ yield $\left(\mathrm{t} \mathrm{ha}^{-1}\right) ; \mathrm{FDM}=$ fruit dry mass $(\mathrm{g} / 100 \mathrm{~g}) ; \mathrm{TA}=$ titratable acidity $(\%$ of citric acid $) ; \mathrm{AAC}=\mathrm{ascorbic}$ acid $\left(\mathrm{mg} 100^{-1}\right.$ fresh mass) and $\mathrm{SSC}=$ total soluble solids; AMB 1= autumn/winter planting (March to August 2013) ; AMB 2= spring/summer planting (October 2013 to Mach 2014).

obtained from the genotypes, which show best averages can be explained by the predominance of additive genetic effects, associated with the fact that both parents did not contribute favorably to the increase of average (Singh et al., 2014; Medeiros et al., 2014). For heterosis exploitation, it is necessary, besides genetic divergence, genotypes showing very good perform per se and which are also complementary (Ramalho et al., 2012). On the other hand, the lowest NFP is interesting when associated with other desirable attributes such as higher FL, DF and AFM in Capsicum species, since it reduces the cost with the harvest, which is largely manual, thus causing a decrease in cost of production without losses or even with increased yield.

For average fruit mass, a range from 4.14 to $15.71 \mathrm{~g}$ was observed (Table 2). This highest average was obtained for HP03, which differed significantly from the average of the two commercial controls. Fruit mass contributes directly to total production and plays an important role when buying chili pepper in natura, because there is difference in the preference of the consumers in relation to this trait, that means that some consumers prefer bigger fruits (heavier), and some other consumers prefer smaller fruits (lighter) (Singh et al., 2014).

In relation to length and diameter of the fruit, which are traits directly related to fruit shape, the authors observed variation among hybrids. The length of the hybrids ranged from 82.62 to $107.15 \mathrm{~mm}$. For fruit diameter, the authors observed a range from 25.25 to $42.19 \mathrm{~mm}$ (Table 2). This variation among hybrids is important as they meet markets with different preferences. According to Lin et al. (2013), based on the shape and size of the fruits, more than 20 types of pepper and sweet pepper markets are known. Onoyama et al. (2010) reported that shape is an important attribute for the consumers of Capsicum and such importance is variable according to the age.

Three experimental hybrids, HP03, HP04 and HP08, did not differ significantly from the genotypes with the best averages of yield, PIM02 and 'BRS Mari' (Table 2), showing a commercial pattern and an agronomic potential, since among these cultivars, one of them is used by the farmers who grow dedo-de-moça chili pepper ('BRS Mari').

In relation to fruit dry mass, since a complex genotype-environment interaction was noticed, the genotype averages were compared in relation to each season, separately. In the first season, cultivar BRS Mari and hybrid HP 03 stood out with the highest averages for FDM, differing significantly from the commercial control 'Ibirajá' (Table 2). 
Table 3. Ranking using non-parametric selection indexes Mulamba \& Mock (1978) and Genotype-Ideotype distance based on agronomic and physicochemical traits of fruits evaluated in three experimental hybrids of pepper, three inbred lines of C. baccatum var. pendulum and two controls of commercial cultivars using average of two seasons. Campos dos Goytacazes, UENF, 2013-2014.

\begin{tabular}{lccccc}
\hline \multirow{2}{*}{ Genotypes } & \multicolumn{2}{c}{ Average of traits } & & \multicolumn{2}{c}{ Selection indexes } \\
\cline { 2 - 3 } \cline { 5 - 6 } & FDM & AAC & & MM & GI \\
\hline HP03 & 17.07 & 85.50 & & $1^{\circ}$ & $2^{\circ}$ \\
HP04 & 14.67 & 51.60 & & $4^{\circ}$ & $6^{\circ}$ \\
HP08 & 15.10 & 49.69 & & $7^{\circ}$ & $5^{\circ}$ \\
PIM01 & 14.70 & 83.85 & & $5^{\circ}$ & $4^{\circ}$ \\
PIM02 & 15.50 & 65.34 & & $3^{\circ}$ & $1^{\circ}$ \\
PIM03 & 12.23 & 41.51 & & $8^{\circ}$ & $7^{\circ}$ \\
'BRS Mari' & 16.93 & 67.43 & & $2^{\circ}$ & $3^{\circ}$ \\
'Ibirajá' & 12.70 & 54.70 & & $6^{\circ}$ & $8^{\circ}$ \\
\hline
\end{tabular}

${ }^{1 / \mathrm{FDM}}=$ fruit dry mass $(\mathrm{g} / 100 \mathrm{~g}) ; \mathrm{AAC}=$ ascorbic acid content $(\mathrm{mg} \mathrm{100-1}$ fresh mass $)$ and MM= Mulamba \& Mock (1978); GI= Genotype-Ideotype index.

In the second season, only HP03 stood out differing significantly from lines PIM01 and PIM03, and like commercial pattern 'BRS Mari'. Sousa \& Maluf (2003) reported that from an agronomic point of view, the genotypes should have high percentage of dry matter per fruit associated to the high yield. In this sense, HP03 is promising, since it is among the genotypes with the best averages for Y and FDM. Such genotype can be useful for industry to produce dehydrated seasonings, as whole fruits or in the form of powder (Lin et al., 2013). In the latter case, where fully ripe fruits are dried and ground in the form of paprika, they can also be used by another market niche in the production of colorants by industries (Srividhya \& Ponnuswami, 2010).

In relation to physicochemical composition of chili pepper fruits tested, for titratable acidity, HP04 differed significantly from the commercial control 'Ibirajá', in which the lowest average was noticed, and it was similar to commercial pattern 'BRS Mari', which showed the highest titratable acidity (Table 2). Rêgo et al. (2011) reported titratable acidity value of $0.68 \%$ in fruits of C. baccatum, much higher than the values found in this study. Evaluating species of Capsicum spp., Borges et al. (2015) obtained an average of $0.364 \%$ for titratable acidity. According to Reis et al. (2015), the lower the titratable acidity in the fruit, the better its conservation status, which directly reflects the quality of a final product for consumption. environment I from 36.87 to 111.19 $\mathrm{mg} / 100 \mathrm{~g}$ of fruit fresh mass. This last value was observed for HP03. In environment II, HP03 remained in the group of better averages (Table 2). This characteristic is important for nutritional value of the fruits, since it contributes to a better retention of color and aroma. This retention results in a longer shelf life of the fruits, which, most of the times, are commercialized in natura (Swamy et al., 2015).

In relation to total soluble solids content, the experimental hybrids obtained averages statistically similar to, at least, one of the commercial controls. SSC in hybrids ranged from 7.20 to $8.60^{\circ}$ Brix (Table 2 ). These values are in accordance with those ranging from 7.7 to $11.6^{\circ}$ Brix reported for C. baccatum by Rêgo et al. (2009). Such values observed in the tested hybrids are important to give flavor and palatability to the fruits.

For the joint analysis of agronomic and physicochemical traits, a genotype $x$ cultivation season interaction of complex nature was noticed only for FDM and AAC (Table 2). Thus, the indexes used in order to select the superior genotypes were based on the average of the two seasons (Table 3).

According to the Mulamba \& Mock
Ascorbic acid content ranged in index (1978), the hybrid HP03 obtained values higher than the evaluated genotypes (Table 3 ). Several advantages are known when using the hybrids of Capsicum spp. (Rodrigues et al., 2016). For a company, the advantage of having a unique product, of which only it owns the specific parental combinations, exploiting without competition the technological product developed is a point to be highlighted. For the producer, the advantage of having a better agronomic performance implies a greater safety in the financial return invested in production. In this study, the advantage of the indication of hybrid HP03 was notorious. Although HP03 shows averages statistically equal to one of the parents and the control ('BRS Mari'), this hybrid has 37\% higher yield than cultivar BRS Mari. For the producer, it is economically advantageous to produce 5 tons more per hectare, and with the reduction of costs, because the harvest is done manually, since the BRS Mari produces twice as many fruits as the cited hybrid. In addition to economic advantages, availability in the Brazilian market of a differentiated hybrid dedo-de-moça with campanulated format, unavailable until then, can result in a higher market value.

Based on Genotype-Ideotype index, among the best evaluated genotypes, HP03 is again the best (Table 3). Considering this index, PIM02 was the first in the ranking. The other genotypes among the four best ones in the ranking were the control 'BRS Mari' in third place and PIM01 in fourth.

Indication of HP03 using selection indexes denotes the superiority of this hybrid in relation to the other genotypes under test. The superior performance of this hybrid is explained by the heterosis, which has been reported in numerous studies evaluating genotypes of the species mentioned, both for agronomic and physicochemical traits (Rodrigues et al., 2012; Medeiros et al., 2014). New field trials with this hybrid will provide information on its adaptability and stability and subsequently meet the requirements for its registration at the Brazilian Ministério da Agricultura Pecuária e Abastecimento (MAPA), so that it can be commercialized. 
Another relevant fact to be highlighted in relation to tested hybrids is that they are resistant to Pepper yellow mosaic virus (PepYMV). Although in the present study no artificial inoculation trial was carried out, resistance to PepYMV in these hybrids was studied and confirmed in preliminary studies (Bento et al., 2009; Rodrigues et al., 2012). The recommendation of genotypes that combine good yield, good quality of fruits with resistance to diseases has great relevance for producers, and impacts agribusiness in a positive way, not only for reducing production costs, but also for the protection of the environment, consumers and producers.

The tested chili pepper hybrids dedode-moça (C. baccatum var. pendulum) presented a constant performance in the two growing seasons based on agronomic and physicochemical traits of the fruits. Among these hybrids, HPO03 stood out, showing superiority when comparing to the other genotypes, confirmed by the selection indexes used.

\section{ACKNOWLEDGMENTS}

Authors thank to Fundação Carlos Chagas Filho de Amparo à Pesquisa do Estado do Rio de Janeiro (FAPERJ) for scholarship awarded to the first author and to Conselho Nacional de Desenvolvimento Científico e Tecnológico (CNPq) for financial support to the research.

\section{REFERENCES}

BARBOZA, GE; AGRA, M, ROMERO, MV, SCALDAFERRO, MA, MOSCONE, EA. 2011. New endemic species of Capsicum (Solanaceae) from the Brazilian Caatinga: comparison with the re-circumscribed $C$. parvifolium. Systematic Botany. 36: 768-778.

BENTO, CS; RODRIGUES, R; ZERBINI, FM; SUDRÉ, CP. 2009. Sources of resistance against the Pepper yellow mosaic virus in chili pepper. Horticultura Brasileira 29: 196-201.

BORGES, KM; VILARINHO, LBO; MELO FILHO, AA; MORAIS, BS; RODRIGUES, RNS. 2015. Caracterização morfoagronômica e físico-química de pimentas em Roraima. RevistaAgro@mbiente 9: 292-299.

CARIAS, CMOM; GRAVINA, GA; FERRÃO, MAG; FONSECA, AFA; FERRÃO, RG; VIVAS, M; VIANA, AP. 2016. Predição de ganhos genéticos via modelos mistos em progênies de café conilon. Coffee Science 11: 39-45.

DE POLLI, H. 1988. Manual de Adubação para o Rio de Janeiro. Seropédica: Ed. Universidade Rural.

CRUZ, CD. 2016. Genes Software-extended and integrated with the R, Matlab and Selegen. Acta Scientiarum. Agronomy 38: 547-552.

CRUZ, CD; CASTOLDI, FL. 1991. Decomposição da interação genótipos $\mathrm{x}$ ambientes em partes simples e complexa. Ceres 38: 422-430.

CRUZ, CD; REGAZZI, AJ; CARNEIRO, PCS. 2012. Modelos biométricos aplicados ao melhoramento Genético. Viçosa: UFV, 480p.

FILGUEIRA FAR. 2012. Novo manual de olericultura: agrotecnologia moderna na produção e comercialização de hortaliças. Viçosa: UFV. 402p.

GONÇALVES, LSA; RODRIGUES, R; BENTO, CS; ROBAINA, RR; AMARAL JÚNIOR, AT. 2011. Herança de caracteres relacionados à produção de frutos em Capsicum baccatum var. pendulum com base em análise dialélica de Hayman. Ciência Agronômica 42: 662-669.

LESSA, LS; LEDO, CAS; SANTOS, VS; SILVA, SO; PEIXOTO, CP. 2010. Seleção de híbridos diploides (AA) de bananeira com base em três índices não paramétricos. Bragantia 69: 525-534.

LIN, S; CHOU, Y; SHIEH, H; EBERT, AW; KUMAR, S; MAVLYANOVA, R; ROUAMBA, A; TENKOUANO, A; AFARISEFA, V; GNIFFKE, PA. 2013. Pepper (Capsicum spp.) germplasm dissemination by AVRDC (The World Vegetable Center): an overview and introspection. Chronica Horticulturae 53: 21-27.

MEDEIROS, AM; RODRIGUES, R; GONÇALVES, LSA; SUDRÉ, CP; OLIVEIRA, HS; SANTOS, MH. 2014. Gene effect and heterosis in Capsicum bacacatum var. pendulum. Ciência Rural 44: 1031-1036.

MAHMOUD, AMA; EL-ESLAMBOLY, ASA. 2015. Production and evaluation of high yielding sweet pepper hybrids under greenhouse conditions. American-Eurasian Journal of Agricultural \& Environmental Sciences 4: 573-580.

MULAMBA, NN; MOCK, JJ. 1978. Improvement of yield potential of the Eto Blanco maize (Zea Mays L.) population by breeding for plant traits. Egyt Journal Gen. Cytol. 7: 40-51.

OLIVEIRA, HS; RODRIGUES, R; BENTO, CS; MEDEIROS, AM; SUDRÉ, CP; COUTO, MF; VIANA, AP. 2015. Towards a new strategy to breed an autogamous plant: A case of study in Capsicum baccatum var. pendulum. Scientia Horticulturae, 192: 279-286.

ONOYAMA, SS; REIFSCHNEIDER, FJB; MOITA, AW; SOUZA, GS. 2010. Atributos de hortaliças sob a ótica de consumidores: estudo de caso do pimentão no Distrito Federal. Horticultura Brasileira 28: 124-132.

PESEK, J; BAKER, RJ. 1969. Desired improvement in relation to selection indices. Canadian Journal of Plant Science 49: 803804.

PINTO, FDO; LUZ, LN; PEREIRA, MG; CARDOSO, DL; RAMOS, HC. 2013. Metodologia dos modelos mistos para seleção combinada em progênies segregantes de mamoeiro. Revista Brasileira de Ciências Agrárias 2: 211-217.

RAMALHO, MAP; ABREU, AFB; SANTOS, JD; NUNES, JAR. 2012. Aplicações da genética quantitativa no melhoramento de plantas autógamas. Lavras: UFLA. 522p.

RÊGO, ER; RÊGO, MM; FINGER, FL; CRUZ, CD; CASALI, VWD. 2009. A diallel study of yield components and fruit quality in chilli pepper (Capsicum baccatum). Euphytica 168: 275-287.

RÊGO, ER; RÊGO, MM; MATOS, IWF; BARBOSA, LA. 2011. Morphological and chemical characterization of fruits of Capsicum spp. accessions. Horticultura Brasileira 29: 364-371.

REBOUÇAS, TNH; VALVERDE, RMV; TEIXEIRA, HL. 2013. Bromatologia da pimenta malagueta in natura e processada em conserva. Horticultura Brasileira 31: 163-165.

RODRIGUES, R; GONÇALVES, LSA; BENTO, CS; SUDRÉ, CP; ROBAINA; AMARAL JÚNIOR, AT. 2012. Capacidade combinatória e heterose para características agronômicas em pimentas do complexo baccatum. Horticultura Brasileira 30: 226-233.

RODRIGUES, R, BENTO, CS, PIMENTA, S, SUDRÉ, CP. 2016. Melhoramento de pimentão e pimentas In: NICK, C; BORÉM, A (eds). Melhoramento de hortaliças. Viçosa: UFV. p. 221-250

REIS, DRD; DANTAS, CMB; SILVA, FS; PORTO, AG; SOARES, EJO. 2015. Caracterização biométrica e físico-química de pimenta variedade biquinho. Enciclopédia Biosfera 11: 454-460.

SILVA, AR; CECON, PR; RÊGO, ER; NASCIMENTO, M. 2011. Avaliação do coeficiente de variação experimental para caracteres de frutos de pimenteiras. Ceres 58: 168-171.

SINGH, P; CHEEMA, DS; DHALIWA, MS GARG, N. 2014. Heterosis and combining ability for earliness, plant growth, yield and fruit attributes in hot pepper (Capsicum annuum L.) Involving genetic and cytoplasmic-genetic male sterile lines. Scientia Horticulturae 168: 175-188.

SMITH, OS; HALLAUER, AR; RUSSEL, WA. 1981. Use of index selection in recurrent selection programs in maize. Euphytica 30: 611-618.

SOUSA, JA; MALUF, WR. 2003. Diallel analyses and estimation of genetic parameters of hot pepper (Capsicum chinense Jacq.). Scientia Agricola 60: 105-11.

SCHWARZBACH, E. 1972. Einige Anwendungsmöglichkeiten elektronischer Datenverarbeitung (EDV) für die Beurteilung von Zuchtmaterial. Arb. Tag. Öesterr. Pflanzenz Gumpenstein 277-287.

SRIVIDHYA, S; PONNUSWAMI, V. 2010. G×E interaction and stability of yield in paprika genotypes (Capsicum annuum var longum) in Tamil Nadu. Electronic Journal of Plant Breeding 3: 297-300.

SWAMY, GN; SRINIVASULU，B; MADHUMATHI, C; TIRUPAL, D. 2015. Evaluation of certain varieties and hybrids of Capsicum for quality attributes under shade net. Journal of Horticulture 2: 124. 